\title{
乙酰丙酮氧钛催化苯酚和碳酸二甲酯的酯交换反应
}

\author{
李碧静 ${ }^{1,2}$, 唐荣芝 ${ }^{1,2}$, 陈 䑣 ${ }^{1, *}$, 王公应 ${ }^{1}$ \\ ${ }^{1}$ 中国科学院成都有机化学研究所, 四川成都 610041 \\ 2 中国科学院研究生院, 北京 100049
}

\begin{abstract}
摘要: 首次将乙酰丙酮氧钣用于苯酚和碳酸二甲酯的酯交换反应合成碳酸二苯酯, 显示出较好的催化活性和很高的酯交换选 择性, 催化剂经 $180{ }^{\circ} \mathrm{C}$ 热处理后, 苯酚转化率可达 $45.8 \%$, 转化数 ( $n$ (苯酚 $) / n(\mathrm{Ti})$ ) 为 96 , 高于有机钛类均相催化剂. 结果表明, 当乙酰丙酮氧钛用量为 $0.2 \mathrm{~g}$ 以上, 开始有副产物苯甲醚生成, 酯交换选择性随催化剂用量的增加而降低. 该催化剂重复使用 5 次后, 苯酚转化率仍可达 $40 \%$ 以上, 酯交换选择性为 $99.9 \%$, 表现出较高的重复使用性能.
\end{abstract}

关键词: 乙酰丙酮氧钣; 碳酸二苯酯; 酯交换; 苯酚; 多相催化剂

中图分类号: 0643 文献标识码: A

收稿日期: 2012-01-09. 接受日期: 2012-02-27.

*通讯联系人. 电话: (028)85250005; 传真: (028)85220713; 电子信箱：chentongw@sina.com.cn

基金来源：中国科学院“西部之光”联合学者项目.

本文的英文电子版(国际版)由 Elsevier 出版社在 ScienceDirect 上出版(http://www.sciencedirect.com/science/journal/18722067).

\section{Transesterification of Phenol and Dimethyl Carbonate Catalyzed by Titanium Oxide Acetylacetonate Catalyst}

\author{
LI Bijing ${ }^{1,2}$, TANG Rongzhi ${ }^{1,2}$, CHEN Tong ${ }^{1, *}$, WANG Gongying ${ }^{1}$ \\ ${ }^{1}$ Chengdu Institute of Organic Chemistry, Chinese Academy of Sciences, Chengdu 610041, Sichuan, China \\ ${ }^{2}$ Graduate University of Chinese Academy of Sciences, Beijing 100049, China
}

\begin{abstract}
Titanium oxide acetylacetonate $\left(\mathrm{TiO}(\mathrm{acac})_{2}\right)$ was found to be a novel and efficient heterogeneous catalyst for the transesterification of phenol and dimethyl carbonate (DMC) to diphenyl carbonate (DPC). The conversion of phenol was $45.8 \%$ on the TiO(acac) 2 pretreated at $180^{\circ} \mathrm{C}$, and the turnover number reached 96 , which was better than the more common organic titanium catalyst. The effect of the amount of catalyst on the catalytic performance was investigated. The transesterification selectivity decreased with catalyst loadings over 0.2 g per $100 \mathrm{ml}$ reactants. At the optimized amount of catalyst the conversion of phenol was $42.4 \%$, and no anisole was detected. In particular, the $\mathrm{TiO}(\mathrm{acac})_{2}$ catalyst proved reusable, and catalytic activity of the recovered $\mathrm{TiO}(\mathrm{acac})_{2}$ was almost the same as that of the fresh catalyst. The conversion of phenol $40.0 \%$ was attained from $\mathrm{TiO}(\mathrm{acac})_{2}$ recovered for the fifth time.
\end{abstract}

Key words: titanium oxide acetylacetonate; diphenyl carbonate; transesterification; phenol; heterogeneous catalyst

Received 9 January 2012. Accepted 27 February 2012.

*Corresponding author.Tel: +86-28-85250005; Fax: +86-28-85220713; E-mail: chentongw@sina.com.cn

This work was supported by the Chinese Academy of Sciences "Western light" United Scholars Program.

English edition available online at Elsevier ScienceDirect (http://www.sciencedirect.com/science/journal/18722067).

碳酸二苯酯 (DPC) 是一种重要的环保型化工中 间体, 可通过卤化、硝化、水解和氨解等反应合成许 多有机化合物和高分子材料, 特别是能替代剧毒光 气与双酚 $\mathrm{A}$ 通过熔融酯交换合成性能优良的聚碳 酸酯. DPC 使用无毒、无污染的碳酸二甲酯 (DMC)
为原料, 与苯酚进行酯交换反应制得 DPC, 是目前 最有前景的非光气合成 DPC 的方法. 该反应在有 机钛和有机锡 ${ }^{[1,2]}$ 均相催化剂作用下, 活性和选择性 都较高, 但均相催化剂存在有毒或不够稳定, 尤其是 与产物分离回收困难等问题. 因此, 开发高活性、高 
选择性和良好稳定性的多相催化剂广受关注, 如复 合金属氧化物 ${ }^{[3 \sim 7]}$ 、杂多化合物 ${ }^{[8,9]}$ 和分子篮类 ${ }^{[10,11]}$ 催化剂均表现出较高的催化活性. 其中, Ti-HMS 具 有最高的酯交换选择性, 无副产物生成, 苯酚转化率 达 $31.4 \%$, 但催化剂不能重复使用; 而 $\mathrm{V}-\mathrm{Cu}$ 复合氧 化物稳定性相对较好, 苯酚转化率为 $37.0 \%$, 但有 $3.2 \%$ 的苯甲醚产生.

本文首次以乙酰丙酮氧铁 $\left(\mathrm{TiO}(\mathrm{acac})_{2}\right)$ 为多相 催化剂, 经 $180^{\circ} \mathrm{C}$ 热处理后用于苯酚和 $\mathrm{DMC}$ 酯交 换合成 DPC 反应, 具有较高活性, 选择性高达 $99.9 \%$ 以上, 可重复使用.

DMC ( $\geq 99 \%$, 山东石油大学胜华化工股份有限 公司) 与苯酚 (AR, 广东光华化学厂有限公司) 的酯 交换反应在 $100 \mathrm{ml}$ 三口瓶中进行. 在 $\mathrm{N}_{2}$ 保护下, 加 入苯酚和乙酰丙酮氧钛 $(\geq 99 \%$, 上海柏笛化学品技 术有限公司) 催化剂, 搅拌下升温至 $175^{\circ} \mathrm{C}$, 滴加 $\mathrm{DMC}$, 反应 $9 \mathrm{~h}$. DMC 与甲醇的共沸物及含主产物 甲基苯基碳酸酯 (MPC) 和 DPC 的反应釜液用气相 色谱仪 (岛津 GC-12B 型) 分析, 校正归一法定量.

图 1 为乙酰丙酮氧钛的 TG-DTA 曲线. 由图可 见, 样品在 $238{ }^{\circ} \mathrm{C}$ 开始分解. 将乙酰丙酮氧钛催化 剂在 $180^{\circ} \mathrm{C}$ 进行热处理后, 其活性和选择性显著增 加, $0.4 \mathrm{~g}$ 催化剂上, 与未经热处理的乙酰丙酮氧钛 相比, 苯酚转化率由 $19.8 \%$ 增加至 $39.4 \%$, 酯交换选 择性从 $98.5 \%$ 增加到 $99.8 \%$.

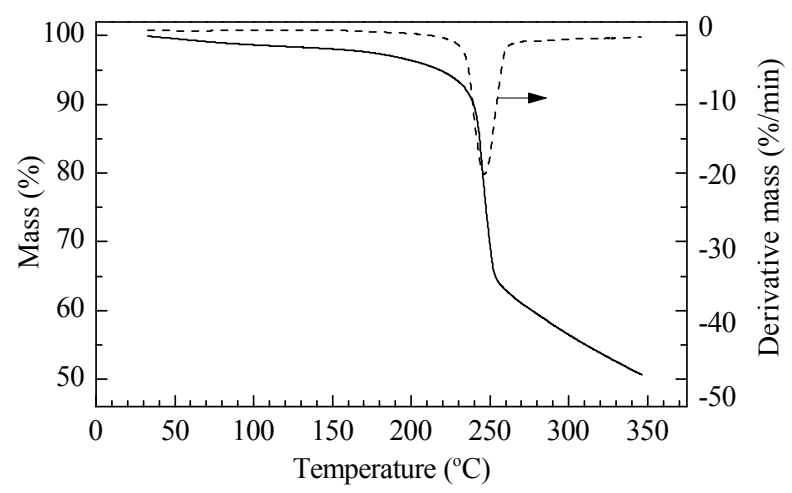

图 1 乙酰丙酮氧钛的 TG-DTG 曲线

Fig. 1. TG-DTG curves of the $\mathrm{TiO}(\mathrm{acac})_{2}$ sample.

乙酰丙酮氧钛催化剂用量对苯酚与 $\mathrm{DMC}$ 酯交 换反应性能的影响见图 2. 可以看出, 苯酚转化率随 着催化剂用量的增加先升高后降低, 至催化剂用量 为 $0.4 \mathrm{~g}$ 时苯酚转化率达最高为 $45.8 \%$, 酯交换选择

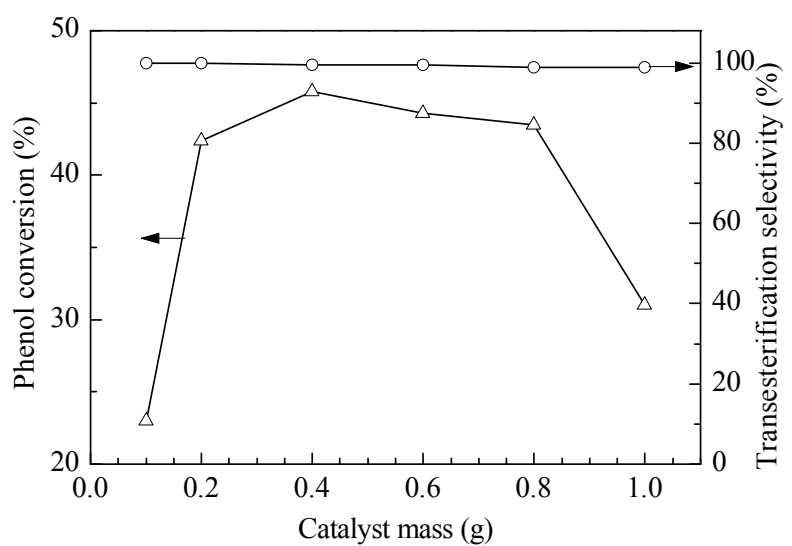

图 2 催化剂用量对酯交换反应合成 DPC 的影响

Fig. 2. Effect of the amount of catalyst on the transesterification reaction. Reaction conditions: $n($ phenol $)=n(\mathrm{DMC})=160,150-180$ ${ }^{\circ} \mathrm{C}, 9 \mathrm{~h}$.

性为 $99.4 \%$, 转化数 (TON, $n$ (苯酚) $/ n$ (Ti)) 为 96 , 高 于有机钛类均相催化剂 ${ }^{[2]}(\mathrm{TON}=92)$. 而酯交换选 择性则不同, 当催化剂用量小于 $0.2 \mathrm{~g}$ 时, 无副产物 生成, 用量在 $0.2 \mathrm{~g}$ 以上时开始有副产物苯甲醚生成, 酯交换选择性随催化剂用量增加呈下降趋势。有机 $\mathrm{Ti}$ 和 $\mathrm{Sn}$ 类化合物均有一定的酸性 ${ }^{[2,14]}$, 适宜的酸性 有利于苯酚和 DMC 的酯交换, 但酸量过大, 易生成 苯酚甲基化产物苯甲醚, 也易使产物 MPC 分解产生 苯甲醚 ${ }^{[9,12 \sim 14]}$. 综合考虑, 催化剂用量为 $0.2 \mathrm{~g}$ 较为 适宜, 此时苯酚转化率和酯交换选择性分别达 $42.4 \%$ 和 $100.0 \%$.

多相催化剂的稳定性是评价其性能的一个重要 指标, 因此本文考察了乙酰丙酮氧钛催化剂的稳定 性. 反应后经过滤回收的催化剂, 用 DMC 充分洗涤, 于 $100{ }^{\circ} \mathrm{C}$ 干燥, $180{ }^{\circ} \mathrm{C}$ 热处理后使用.

反应结果如表 1 所示, 乙酰丙酮氧钛重复使用

\section{表 1 苯酚和 DMC 酯交换合成 DPC 中乙酰丙酮氧钛的稳 定性}

Table 1 Reuse of $\mathrm{TiO}(\mathrm{acac})_{2}$ in the transesterification of DMC and phenol

\begin{tabular}{cccc}
\hline \multirow{2}{*}{ Run } & Phenol conversion & \multicolumn{2}{c}{ Yield (\%) } \\
\cline { 3 - 4 } & $(\%)$ & MPC & DPC \\
\hline 1 & 42.4 & 23.7 & 18.7 \\
2 & 41.5 & 21.9 & 19.6 \\
3 & 39.8 & 21.2 & 18.6 \\
4 & 42.6 & 23.9 & 18.7 \\
5 & 40.3 & 20.7 & 19.6 \\
\hline
\end{tabular}

Reaction conditions: $n($ phenol $)=n($ DMC $)=160, m($ catalyst $)=0.2 \mathrm{~g}$, $150-180^{\circ} \mathrm{C}, t=9 \mathrm{~h}$. 
5 次, 苯酚转化率均在 $40.0 \%$ 以上, 无副产物生成.

综上所述, 乙酰丙酮氧钛在苯酚和 DMC 的酯 交换反应中表现出高的苯酚转化率和酯交换选择性, 酯交换选择性和稳定性明显优于其它多相催化剂. 在适宜的反应条件下, 苯酚转化率即可达 $42.4 \%$, 酯 交换选择性为 $100.0 \%$, TON 为 89 , 与最好的 $\mathrm{Ti}$ 类 均相催化剂相当. 因此, 是一种适用于苯酚和 DMC 酯交换合成 DPC 的高效多相催化剂.

\section{参 考 文 献}

1 Du Z P, Kang W K, Chen T, Yao J, Wang G Y. J Mol Catal A, 2006, 246: 200

2 Niu H Y, Yao J, Wang Y, Wang G Y. J Mol Catal A, 2005, 235: 240

3 Mei F M, Pei Z, Li G X. Org Process Res Develop, 2004, 8: 372

4 Zhou W Q, Zhao X Q, Wang Y J, Zhang J Y. Appl Catal A, 2004, 260: 19

5 葛金金, 李碧静, 胡静, 陈形, 王公应, 胡徐腾. 化学学报 (Ge X, Li B J, Hu J, Chen T, Wang G Y, Hu X T. Acta Chim Sin), 2011, 69: 2328

6 童东绅, 陈娅, 姚洁, 王越, 王公应, 石大川, 李正, 陈 志明. 催化学报 (Tong D Sh, Chen T, Yao J, Wang Y, Wang G Y, Shi D Ch, Li Zh, Chen Zh M. Chin J Catal), 2007, 28: 190

7 Cao M, Meng Y Z, Lu Y X. Catal Commun, 2005, 6: 802

8 韩华俊, 陈形, 姚洁, 王公应. 催化学报 (Han H J, Chen T, Yao J, Wang G Y. Chin J Catal), 2006, 27: 7

9 Chen T, Han H J, Yao J, Wang G Y. Catal Commun, 2007, 8: 1361

10 罗淑文, 陈形, 童东绅, 曾毅, 雷永诚, 王公应. 催化学 报 (Luo Sh W, Chen T, Tong D Sh, Zeng Y, Lei Y Ch, Wang G Y. Chin J Catal), 2007, 28: 937

11 Li Z H, Cheng B W, Su K M, Gu Y, Xi P, Guo M L, Cheng B W. J Mol Catal A, 2008, 289: 100

12 Braunstein P, Lakkis M, Matt D, Lecolier S. J Mol Catal, 1987, 42: 353

13 Barcelo G, Grenouillat D, Senet J-P, Senyey G. Tetrahedron, 1990, 46: 1839

14 Du Z P, Xiao Y H, Chen T, Wang G Y. Catal Commun, 2008, 9: 239

\section{英 译 文 \\ English Text}

Diphenyl carbonate (DPC) is an important chemical intermediate and is used extensively for the preparation of many organic compounds and polymer materials, especially for the preparation of polycarbonates without the use of phosgene bisphenol A in a melt transesterification. Trans- esterification of phenol and dimethyl carbonate (DMC) is considered to be the most promising method for the industrial production of DPC because DMC is a relatively "green" raw material. The synthesis of DPC via transesterification is usually carried out in the liquid phase using homogeneous catalysts such as organic tin or titanium compounds $[1,2]$. However, the titanium and tin compounds are too poisonous to be considered environmentally benign catalysts. Moreover, homogeneous catalysts are generally difficult to separate from the final product. Solid catalysts are generally the focus of current research. Until now, several heterogeneous catalysts had been investigated for the transesterification, such as complex metal oxides [3-6], heteropoly compounds $[7,8]$, and molecular sieves $[9,10]$. Ti-HMS shows excellent transesterification selectivity, avoiding the production of anisole and giving a $31.4 \%$ conversion of phenol, but Ti-HMS cannot be reused. The stability of the $\mathrm{V}-\mathrm{Cu}$ complex oxide is better than other heterogeneous catalysts, and the conversion of phenol was $37.0 \%$. However, $3.2 \%$ of the byproduct anisole was also produced.

In this work, $\mathrm{TiO}(\mathrm{acac})_{2}$ is the first heterogeneous catalyst for the transesterification of DMC and phenol in the synthesis of DPC to the best of our knowledge. It was found that $\mathrm{TiO}(\mathrm{acac})_{2}$ is a highly efficient and stable heterogeneous catalyst with greater than $99.9 \%$ transesterification selectivity.

The transesterification of phenol (AR, Guangdong Guanghua Sci-Tech Co., Ltd., China) and DMC ( $\geq 99.9 \%$, Huasheng Co. Ltd., Shandong University of Petroleum, China) was carried out in a $100 \mathrm{ml}$ three-neck round-bottomed flask under a nitrogen atmosphere. The mixture of phenol and $\mathrm{TiO}(\mathrm{acac})_{2}(\geq 99.9 \%$, Shanghai Dibo Chemical Co. Ltd., China) was stirred and heated to $175^{\circ} \mathrm{C}$. DMC was added dropwise, and the reaction left for $9 \mathrm{~h}$. $\mathrm{TiO}(\mathrm{acac})_{2}$ was used as a heterogeneous catalyst, which is insoluble in the reaction system. The products and the azeotrope of DMC with methanol were analyzed by GC (Shimadzu, GC-12B).

Thermal analysis (Fig. 1) of the catalyst indicates that the decomposition temperature of $\mathrm{TiO}(\mathrm{acac})_{2}$ is $238^{\circ} \mathrm{C}$. When $\mathrm{TiO}(\mathrm{acac})_{2}$ was pretreated at $180^{\circ} \mathrm{C}$, the catalytic activity the transesterification selectivity increased significantly. The conversion of phenol increased from $19.8 \%$ to $39.4 \%$, and the transesterification selectivity increased from $98.5 \%$ to $99.8 \%$ with the use of $0.4 \mathrm{~g}$ of $\mathrm{TiO}(\mathrm{acac})_{2}$.

Figure 2 shows the effect of the amount of catalyst on the transesterification. The conversion of phenol increased with increasing catalyst amount up to $0.4 \mathrm{~g}$, giving the highest phenol conversion of $45.8 \%$ and transesterification selectivity of $99.4 \%$. Meanwhile, the turnover number (TON, $n($ phenol $) / n(\mathrm{Ti}))$ reached 96 , which is superior to that of the organic titanium homogeneous catalyst [2] $(\mathrm{TON}=92)$. 
However, the transesterification selectivity decreased as the amount of catalyst increased. No anisole was produced using less than $0.2 \mathrm{~g}$ of the catalyst. The weak acidity of $\mathrm{TiO}(\mathrm{acac})_{2}$ is advantageous to the transesterification of phenol with DMC to DPC, but in excess, the acidity produces anisole by methylation of phenol or by the decomposition of MPC was detected [8,11-14]. Therefore, $0.2 \mathrm{~g}$ was the optimized amount of catalyst giving $42.4 \%$ conversion of phenol and $100 \%$ transesterification selectivity.

Stability is an important factor for heterogeneous catalysts. $\mathrm{TiO}(\mathrm{acac})_{2}$ was recovered by filtration, washed with DMC, dried at $100{ }^{\circ} \mathrm{C}$, and again heat treated at $180{ }^{\circ} \mathrm{C}$.

Table 1 shows that the catalytic activity of the recovered $\mathrm{TiO}(\mathrm{acac})_{2}$ was similar to fresh catalyst. The conversion of phenol remained above $40.0 \%$, and no anisole was detected.
For the transesterification of DMC and phenol, $\mathrm{TiO}(\mathrm{acac})_{2}$ has been found to be a novel and efficient heterogeneous catalyst, with both high phenol conversion and good transesterification selectivity. In particular, the selectivity and stability of $\mathrm{TiO}(\mathrm{acac})_{2}$ are superior to other heterogeneous catalysts. Under the optimized reaction conditions, using 0.2 $\mathrm{g} \mathrm{TiO}(\mathrm{acac})_{2}$, the conversion of phenol was $42.4 \%$ and the transesterification selectivity was $100 \%$. The TON reached 89 , which is similar to the best homogeneous catalyst. Therefore, $\mathrm{TiO}(\mathrm{acac})_{2}$ is a highly efficient heterogeneous catalyst for the transesterification of phenol and DMC to DPC.

Full-text paper available online at Elsevier ScienceDirect http://www.sciencedirect.com/science/journal/18722067 